\title{
The Economic and Ecological Contexts of Urbanization in the Great Hungarian Plain during the Eighteenth and Nineteenth Centuries*
}

\author{
Zsolt Szilágyi \\ University of Debrecen, Institute of History, 4002-Debrecen, Pf. 400. Hungary; \\ szilagyi.zsolt@arts.unideb.hu
}

Received 13 August 2021 | Accepted 12 October 2021 | Published online 3 December 2021

\begin{abstract}
There is abundant research on the history of urbanization in the Carpathian Basin with a special focus on the history of urbanization in the Great Hungarian Plain. Over the past years, there have been investigations concerning climate and historical ecology issues, as well as economic and social history, the results of which enable us to obtain an overview of the complex processes in the eighteenth and nineteenth centuries.

It has been confirmed that prior to the Industrial Age (1850), climate change had made a profound impact on the conversion of the settlement network in the terrain and on the expansion of livestock farming. The climate in the seventeenth century seems to have been cooler and more humid, thus in the Great Hungarian Plain there were large areas covered with water. This significantly restricted the possibilities of crop cultivation as well as population growth. The warming-up period in the eighteenth century resulted in the shrinking of areas covered in water, the transition to flood plain farming and the extension of plough land crop cultivation, ultimately leading to population growth. There is evidence that by the turn of the eighteenth-nineteenth centuries, grain trade in the Carpathian Basin had been integrated into the Central European continental crop trading system, however, livestock farming was unique to the Great Hungarian Plain. From the mid-nineteenth century, due to the construction of the railway system in the Great Hungarian Plain, which revolutionized cargo transport, plus due to river regulations and drainage works, the economic structure of the area saw profound changes. In the meanwhile, the population and labor force supply were also increasing at a rapid rate. Marshlands and meadows were replaced by arable land and an increasingly growing crop production, which provided the foundations for the grain trade. Thus, new market centers emerged in the Great Hungarian Plain. Between 1828 and 1925, the number of market centers went up by 293 , which represents an elevenfold rise. The growing density of the market center system significantly defined not only various aspects of urbanization, but also the general modernization of the Great Hungarian Plain.
\end{abstract}

The purpose of my research is to analyze how changes in the climate influenced the settlement network, and the social and economic profile of the Great Hungarian Plain in the period concerned.

The research was conducted within the MTA BTK Lendület Ten Generations Research Group. The scope indicated in the title is handled flexibly. 
Why was the favorable picture of a dynamically improving and modernizing Great Hungarian Plain at the turn of the nineteenth and twentieth centuries conceptualized by the public as an underdeveloped area characterized by a series of economic and social tensions? How do all these factors contribute to the revision of the emerging historiographic picture of the economic and social consequences of the Trianon Peace Treaty?

Keywords: Great Hungarian Plain, climate change, water regulations, crop trade, urbanization, market centers, homesteads, Trianon (Peace Treaty)

\section{Introduction}

The Great Hungarian Plain ${ }^{1}$ is located in the central region of the Carpathian Basin, covering 100,000 square kilometers. As part of the Austro-Hungarian Monarchy, prior to World War I, the Great Hungarian Plain belonged to the territory of historical Hungary. As a consequence of the Treaty of Trianon (1920), ${ }^{2}$ which terminated the war, the new Hungarian country borders affected the area of the Great Hungarian Plain: the north-eastern part was proclaimed to belong to the Czechoslovak Republic, the eastern region was assigned to eastern Romania, and the southern section came under the control of the State of Slovenes, Croats, and Serbs. A small area totaling half of the original Great Hungarian Plain remained within the borders of the newly drafted Hungarian territory, later referred to as the post-Trianon Great Hungarian Plain.

Due the geographical features of the landscape, the region was formed by river erosion and accumulation processes over the last millennia. The Great Hungarian Plain is surrounded by an extended terrain of hills and mountains, the major part of which belong to the watershed of the Tisza, the main river of the area. Hence, the Tisza and its confluents find their running-down terrain mostly onto the Great Hungarian Plain. In the past, the lower lying, enclosed basins accumulated the river water, which enabled the formation of areas permanently or temporarily covered in water. Until the mid-nineteenth century, this water world with its very diverse flora and wild fauna had characterized not only the natural geographical identity of the terrain, but also defined its economic structure and settlement network as well as the daily lives of local residents.

Recent Hungarian research into climate history, ${ }^{3}$ which complies with the relevant international research outcomes, ${ }^{4}$ enables us to make deductions about

1 Beluszky, A Nagyalföld történeti földrajza.

2 Romsics, A trianoni békeszerződés.

3 Kern, "Éghajlati és környezeti változások"; Rácz, Magyarország éghajlattörténete; Rácz, "Mi a kis jégkorszak?”; Rácz, “Mezőgazdasági terméskatasztrófák”; Rácz, A kis jégkorszak éghajlati változásainak hatása.

$4 \quad$ Glaser and Riemann, "A Thousand-Year Record"; Dobrovolný et al., "Monthly, Seasonal and Annual Temperature Reconstructions”; Luterbacher et al., "European Summer Temperatures"; Ljungqvist et al., "European Warm-Season Temperature." 
past climate change in the Carpathian Basin. Based on the details derived from the literature, the seventeenth century, especially its last third, was marked by a cool and humid climate phase within the Carpathian Basin. In contrast, the eighteenth century featured gradual warming-up. ${ }^{5}$ Research by Lajos Rácz has found that the cooling down phases within the Carpathian Basin usually coincided with humidity, while the dry warming-up periods were characterized by the shrinking of areas permanently or temporarily under water. Accordingly, within the Carpathian Basin (and within the Great Hungarian Plain as well), the most important factors defining its climate were not primarily the alterations in temperatures, but rather the amounts and patterns of precipitation, particularly in view of agricultural economy. ${ }^{6}$ The humidity reconstruction drawn up on the basis of Pfister's methods shows that the period between approximately 1650 and 1790 was generally more humid than the subsequent period between 1790 and 1860, although the 1680s and the 1690s and the years between 1740 and the 1760s appear to have been dry. The period between 1860 and 1940 saw more precipitation again.

Recent historiography has had a prominent focus on ecological approaches, ${ }^{7}$ attaching particular importance to the "challenge and response" concept created by Arnold Toynbee, ${ }^{8}$ a concept also applied in Vera Bácskai's volume, Városok Magyarországon az iparosodás elött (Cities in Hungary Prior to Industrialization). ${ }^{9}$ She demonstrates that urbanization within the Carpathian Basin was a unique process which may be compared to urbanization elsewhere in Europe, but in order to understand the essence of a capitalist structure and urbanization in the Great Hungarian Plain, we primarily need to interpret the shifts within the terrain, also taking into consideration internal differences within it. ${ }^{10}$ Thus, the analysis requires not only an external examination but an internal context as well. ${ }^{11}$ In other words, to understand the city, the basis of its context can be provided by the city itself (urban as a process), ${ }^{12}$ an analogy that may lead to the deduction that the terrain (regions) may serve as the (internal) context of their own interpretation. Consequently, the landscape will be expounded as a process, since its continuous changes will serve as the foundation of the interpretation. To comprehend the ideas noted, we need to see

5 Rácz, A kis jégkorszak éghajlati változásainak hatása, 251, 255.

6 See Rácz, Magyarország éghajlattörténete.; Rácz, “Mi a kis jégkorszak?”; Rácz, “Mezőgazdasági terméskatasztrófák”; Rácz, A kis jégkorszak éghajlati változásainak hatása.

7 E.g., R. Várkonyi and Kósa, eds, Európa híres kertje; R. Várkonyi, ed., Táj és történelem; Pinke, "Alkalmazkodás és felemelkedés."

8 Toynbee, “Tanulmány a történelemröl”; see also Toynbee, “Tanulmány a történelemröl (részlet).”

9 Bácskai, Városok Magyarországon.

10 Bácskai, Városok Magyarországon, 64.

11 E.g., Benda, Zsellérből polgár; Kövér, A tiszaeszlári drama.

12 Hershberg, “The New Urban History”; see Gyáni, Az urbanizáció társadalomtörténete, 5-15. 
that, especially in the case of the Carpathian Basin as a basin, the relationship and its perception between humans and the landscape ${ }^{13}$ went through major changes in time and space. It is vital to clarify the pace of these changes, their dynamics and the complex interaction of how various processes influenced each other.

\section{The economic structure of the Great Hungarian Plain in the seventeenth and eighteenth centuries}

There is a strong likelihood that seventeenth century geographical-environmental changes were induced by the cooling down period and its excess rainfall, which had significantly changed the practice of land use by the end of the century. On the one hand, as our focus is a basin, due to the flow of water from the surrounding mountains (watersheds), gradually more areas were covered in water within the Great Hungarian Plain, and for gradually longer periods of time, which must have been a remarkable experience for the entire community (a question for forthcoming examinations). Hence, the enlarged water surface was an even more determinant defining element of the landscape. On the other hand, due to these environmental transformations, livestock farming in the flood-plain areas was becoming more significant, which gave rising economic value and potential to the water-prone regions. There was a growth in the size of grass pastures and hayfields happening in parallel with the shrinking size of land used for crop farming. As a result, in order to satisfy the population's demand for grain from local resources, based on (formerly) arising supply and demand factors, presented further challenges for the communities in the Great Hungarian Plain, which had a pivotal impact on demographic changes within the region. Therefore, there are strong reasons to assume that besides the conditions stemming from the Turkish occupation and other circumstances, climate change made a considerably more substantial impact on demographic processes in the Carpathian Basin than has been presumed. This is especially true for the changing population numbers in the Great Hungarian Plain in the seventeenth century. The hypothesis is reinforced by the fact that in the seventeenth century, there was no significant population growth in the regions of Europe that, unlike the Great Hungarian Plain, were not occupied by the Ottomans (we should consider though that in 1618-1648 they suffered the Thirty Years' War); the growth was actually stalled or even decreased in certain places. The trends of population growth within the Carpathian Basin followed Central and Eastern European patterns and "did not differ from the main processes that were typical of the region." 14

As we have seen, climate change exerted a generally unfavorable impact on

\footnotetext{
13 See Mendöl, Táj és ember.

14 Ágoston and Oborni, A tizenhetedik század története, 98.
} 
population growth in the Great Hungarian Plain, while the gradual extension of the temporarily water-covered areas (pastures and hayfields) boosted livestock farming at the expense of crop production. Besides the losses suffered due to the Ottoman occupation (1526-1699), the cooler and more humid climate was partly responsible for the further decrease in the population. However, lower population numbers resulted in more favorable conditions for smaller communities gaining personal wealth and for the urbanization of the Great Hungarian Plain. Therefore, from the perspective of later processes, on the one hand, this phase meant a major "leap" in the socio-economic transformation of the Great Hungarian Plain. On the other hand, it also refers to the idea that behind the previously well-famed and regularly cited "capital accumulation" within the Great Hungarian Plain, which we know from historical narratives and from the narratives of Hungarian literature, ${ }^{15}$ in addition to the continental food demand and the price revolution that lasted until the first third or the middle of the seventeenth century, ${ }^{16}$ there was also the strong influence of the effects of climate change.

During the fifteenth century, the Great Hungarian Plain started to be gradually desertified, and the process was accelerated by the Ottoman occupation in the sixteenth century. The rate of abandoning the settlements, in other words the internal (regional) migration, may have been partly due to military actions, but partly also to climate change. Due to the changes in the climate, the parcels of land kept out of cultivation were favorable for livestock farming. Taking advantage of the opportunities opening up, the inhabitants and authorities of market towns in the Great Hungarian Plain tried to lease plots of land and to extend their economic areas for the growing number of livestock. Hence, it was a priority for market towns to link the grasslands to the towns for a long time, which had fundamental consequences for the overall settlement network in the Great Hungarian Plain. More specifically, the areas surrounding the market towns could not be resettled by the residents of the former villages mainly due to economic reasons. In this sense, it was the market towns themselves that hindered the process of "re-villageing" within the Great Hungarian Plain. ${ }^{17}$ Consequently, the population density of the Middle Ages could not be reached again, partly because growth was strongly limited by the expansion of water-prone areas. Overall, it appears that all these factors contributed cumulatively to the conservation of the Great Hungarian Plain's settlement network of the seventeenth century.

The eighteenth century warming up with more moderate rainfall, which represented another climate change, played a vital role in the shrinking of the water-covered areas and in modifying the conditions of livestock farming. In turn, these factors

15 Rácz, Városlakó nemesek; Mikszáth, "Beszélő köntös."

16 Orosz, "Árforradalom, konjunktúrák."

17 Orosz, Tanulmányok, 15; Mendöl, Táj és ember, 67; Weis, Mai magyar társadalom, 15. 
had an adverse effect on the previous practices of capital accumulation. Shifts in the economic structure became "unavoidable" due to the additional effect of the Great Hungarian Plain becoming part of the Habsburg Empire after the lengthy Ottoman rule. A new network of administrative services was established, new tenures were created, and novel economic opportunities arose within the region. In addition, partly due to the arrival of new settlers and partly to higher natural reproduction numbers, in the eighteenth century the population in the Great Hungarian Plain started to grow. ${ }^{18}$ The water-prone areas previously used only for farming started to expand, providing favorable conditions for crop production and population growth. Rising population density (due to the traditional economic structure) implied a higher risk of overpopulation. Therefore, more farmland, as well as the introduction of local water management regulations and constructions were necessary. In the last third of the eighteenth century, water regulation was started by the demolition of watermills (also) within the marshlands of the Sárrétek (literally: Mudmeadows) in order to eliminate the harmful effects of emerging floods..$^{19}$ By the end of the century, more and more parcels of dry land were converted into arable agricultural territories. In turn, the mostly positive outcomes of these developments led to further water regulation work for serving local interests. ${ }^{20}$

However, the warming-up period launched another completely different process in the regions where sandy soils had developed over the last millennia. In the areas of the so-called Nyírség and the region between the Danube and the Tisza, there were uninterrupted stretches of sandy land. ${ }^{21}$ However, during earlier centuries, but particularly by the end of the seventeenth century, extensive livestock farming resulted in overpasturing. ${ }^{22}$ As a consequence, the formerly fixed sandy surfaces started to move. The threat of the "emergence of quicksand" was presumably strengthened by the warmer and drier climate, leading to the decrease of river runoff, the shrinking of flood-prone areas, coupled with lower levels of soil water. The local answer to the environmental challenge of quicksand was to harden the moving sand. ${ }^{23}$ The solution was provided by the field gardens (mezei kertek) and the lodgings on the towns' peripheries that had been established in the countryside

18 Wellmann, "Magyarország népességének fejlődése”; Kováts, "A népességfejlődés vázlata"; Kováts, "A Kárpát-medence népesedési viszonyainak alakulása”; Öri, "A természetes szaporodás alakulása”; Dövényi, "A migráció szerepe.”

19 Dóka, A Körös és Berettyó vízrendszer szabályozása.

20 Szilágyi, "Sárrét posztmodern perspektívában," 121-22.

21 Pécsi, ed., Magyarország nemzeti atlasza, 78-79; Mezősi, Magyarország természetföldrajza, 214-7; see Pécsi, Negyedkor és löszkutatás.

22 Szilágyi, Homokváros, 30, 148-49.

23 Szilágyi, Homokváros, 30-34, 50-63. 
in the earlier centuries. ${ }^{24}$ Although, the continuity with the Middle Ages is not confirmed by extant resources, ${ }^{25}$ it is still presumable that these field gardens and lodgings have their precedents in the Middle Ages. ${ }^{26}$ Lodgings were special individual "settlements" suited for livestock farming. ${ }^{27}$ Both forms of "settlements" outside towns underwent modifications in their functions due to climate change, increasing population growth, and various solutions for meeting the arising challenges. In the long run, the field garden combined with the lodging must have been the basis for the new settlement type, the homestead.

Due to the low settlement and population density in the Great Hungarian Plain, the agricultural cultivation of fields must have been a more complex task than in other regions. Due to the above reasons, in most cases re-inhabiting villages was out of the question in the eighteenth century. Therefore, the mushrooming of homesteads can be interpreted as a response that market town societies were giving to environmental changes and demographic expansion. István Orosz has recently pointed out that homesteads emerged in great numbers near those settlements (towns and villages) where waste-land cultivation was standard practice. At the beginning of the eighteenth century, over a hundred settlements of this type were recorded in the Great Hungarian Plain. ${ }^{28}$ I would argue that in this phenomenon as well, climate change must have played a decisive role. This is especially valid for cases where the change in the amount of rainfall caused profound shifts in surface-water and flora coverage, and where due to overpasturing new terrains more sensitive to the hydrological impacts of climate change emerged: in other words, in places where flexible cultivation methods had to be employed, adapting to environmental and demographic modifications.

The warming-up period of the eighteenth century generally ensured favorable conditions for agriculture across Europe. In the first third of the century, because of the agricultural revolution, Europe's population showed a rapid rise, going from 110 million to at least 180 million. ${ }^{29}$ The larger demand for food fundamentally transformed grain trade on the continent. ${ }^{30}$ We know from research done by Dezső Dányi that at the end of the eighteenth century, crop trade in the Carpathian Basin, particularly in the Great Hungarian Plain, started to be integrated into the European

\footnotetext{
24 Szilágyi, "Alkalmazkodó mezőváros."

25 Solymosi, "A tanyarendszer," 90-92.

26 See Szabó, Kecskeméti tanyák; Für, Kertes tanyák; Iványosi-Szabó, Kecskemét gazdasági fejlődése; Rácz, "A tanyarendszer kialakulása."

27 Mendöl, Általános településföldrajz, 12, 236.

28 Orosz, Tanulmányok, 59.

29 Papp, “A népességviszonyok," 23.

30 Ljungqvist et al., "The Significance of Climate Variability."
} 
trading system. ${ }^{31}$ It is clearly seen that the centers lying at the edge of the terrain were the predominant winners of this economic process, and only a few internal crop trading centers (e.g., Debrecen and Szeged) had a similarly advantageous location and market position. ${ }^{32}$ In order to enjoy the economic benefits of joining the international trading network within the Great Hungarian Plain, the transportation system also had to be revolutionized..$^{33}$ At the same time, I would argue that it was this crop trading in the Carpathian Basin, integrated into the Central European system and emerging early (in terms of later modernization) at the turn of the eighteenth-nineteenth centuries, that established the most vital condition for the accelerated transformation of the economic and social systems of the Great Hungarian Plain. And in turn, this trading system had been strongly influenced by the effects of climate change up to the industrial age in the mid-nineteenth century (or at least up to the turn of the eighteenth and nineteenth centuries).

Research done by Fredrik Charpentier Ljungqvist and his colleagues has clearly demonstrated that in Europe in the Modern Era climate change and the prevailing price index rates for crops were always in close correlation. Lower summer average temperatures led to rising crop prices, while higher temperatures resulted in decreasing prices $(\mathrm{r}=-0.41$; in case of a moving average for a decade, the reverse relationship was even more marked, -0.63$).{ }^{34}$ Their research also reveals that the precipitation of rainfall was less likely to affect crop prices than temperature. Nevertheless, summers with more rainfall were usually followed by a rise in crop prices the following year (weak positive correlation). The analysis underlines that both extensive amounts of rainfall and summer droughts exerted a negative impact on crop prices. It is of particular significance for our study that they further highlight that the correlation is tighter between the amount of rainfall and crop prices at the level of meso and micro regions than at the level of macro regions. This idea actually implies that in the case of a region like the Great Hungarian Plain, a stronger positive correlation can be assumed between rainfall and crop prices typical of the preindustrial period than in the case of Western or Central Europe. This correlation holds even more strongly for the Great Hungarian Plain, where a half-a-meter difference in water level may have defined which parcels of land were flooded and which surfaces stayed dry. In addition, the Great Hungarian Plain was surrounded by mountains from where most rivers ran into this area. At the point where they reached the low-lying areas, they started winding, and a part of their water runoff accumulated in the enclosed flat low-lying terrains. As for local crop pricing, it is a well-established argument that

\footnotetext{
31 Dányi, Azélet ára.

32 Glósz, Gabonakereskedelem Magyarországon, 241-52; see Pinke, "Alkalmazkodás és felemelkedés," 165-75.

33 Katus, "A szállítás forradalma"; Katus, "Szállítási forradalom Magyarországon."

34 Ljungqvist et al., "The Significance of Climate Variability."
} 
within the Carpathian Basin, especially in the Great Hungarian Plain, rainfall must have been a more determinant factor than temperature. ${ }^{35}$

The economic structure of the Great Hungarian Plain in the Modern Era could be maintained and the economic growth was sustainable up to the point when the terrain reached (under the given conditions) the limits of its sustainability. As long as the pasture and the hayfield areas could be further expanded, the economic structure ensured (both at the individual and the collective level) a diversity of accumulation frames, while also providing opportunities for the population's social differentiation in the market towns of the Great Hungarian Plain. When the environmental circumstances started to change, the elements of the economic structure (including people) also started to adjust to the newly emerging situation.

\section{Nineteenth century changes: unsustainable economic development}

Besides climate change, we need to remember that it caused considerable modifications to the Great Hungarian Plain that during the sixteenth-seventeenth centuries most of the terrain was under Ottoman occupation. The settlement structure went through profound transformations. Population numbers dropped, slowing down various other economic processes. In some locations, the average population density fell to a handful of citizens per square kilometer, and by the beginning of the eighteenth century, this number went up to no more than approximately eight persons per square kilometer (while elsewhere, such as the Hungarian Uplands or Transylvania, this figure was doubled) ${ }^{36}$ According to Gyula Benda, the population resettlement seems to have happened in two phases. Initially, in the early eighteenth century, immigration and the relocation of certain groups were more characteristic, and in the southern region of the Great Hungarian Plain (Banat [Bánát]) relocation continued to be typical in the forthcoming periods as well. ${ }^{37}$ In contrast, in the second half of the century, besides immigration, natural reproduction was an increasingly more determinant factor in the population growth of the Great Hungarian Plain. ${ }^{38}$ Between 1550 and 1780 the number of residents is estimated to have increased from 4 or 4.5 million to 6.5 million. ${ }^{39}$ Most of this growth of 2 or 2.5 million people happened in the eighteenth century. Based on quantitative data, this development correlates with the rise in agricultural production. ${ }^{40}$

35 See Rácz, "Mezőgazdasági terméskatasztrófák”; Rácz, A kis jégkorszak éghajlati változásainak hatása.

36 Barta, A tizennyolcadik század története, 153.

37 Benda, Társadalomtörténeti tanulmányok, 205.

38 Benda, Társadalomtörténeti tanulmányok, 206.

39 Benda, Társadalomtörténeti tanulmányok, 205

40 Benda, Társadalomtörténeti tanulmányok, 207. 
By the eighteenth century, crop cultivation had developed two main centers in the Carpathian Basin: the Little Hungarian Plain in the west, and the Great Hungarian Plain (in its Central and Southern Transtisza region and in the Bánát). ${ }^{41}$ It is no coincidence that in the early phases of railway construction, these were the regions to be integrated into the railway circulation. ${ }^{42}$ (the region between the Danube and the Tisza, and the north-eastern part of the Great Hungarian Plain had a different profile with growing fruit and vegetables or tobacco). Prior to the mid-nineteenth century, the amount of grain produced locally outweighed the demand imposed by increased population numbers only to a small extent, but later, grain production saw a phase of faster growth. Based on the details at hand, the earlier slight rate of growth could not result in more exports; instead, it contributed to the emergence of new consumption patterns, while there was a decreasing trend in livestock farming and breeding. The rapid growth of exporting grain started only in 1850-1870, which affected positively the grain production in the Great Hungarian Plain. ${ }^{43}$

Before 1850, plant cultivation in plough lands could only be started via breaking pastures and hay fields for arable land. However, following the "landmark date", attributable to the launch of water regulation, it became possible to gain extensive farmland in the drained and flood protected terrains. This is the period of history marked by the migration of the workforce from the northern mountainous and overpopulated territories to the inner regions of the Great Hungarian Plain. The destination of migration was the newly broken lands taken into plough land cultivation.

Based on these developments, it may be concluded that the repeated boom in the demand for grain had a decisive influence on the economy, society, and urbanization of the Carpathian Basin. From the second half of the eighteenth century to the termination of the Napoleonic wars, there was a traceable rise in crop prices in the European market, which is proven to have been due to the effects of climate change ${ }^{44}$ and was accompanied by a drawn out economic downturn. The following phase was a major or long-lasting grain boom in the second half of the nineteenth century (1852-1878). ${ }^{45}$ Research makes it evident that a distinction needs to be made between industrial and preindustrial conditions. Following the 1850s, the impactful processes (economic, social, infrastructural, etc.) were completely different from those that defined prior periods. In addition, there is a strong likelihood that climate change played a lesser role in them. Economic modernization was laid upon new foundations (which is to be investigated by later studies).

\footnotetext{
41 Benda, Társadalomtörténeti tanulmányok, 201.

42 Benda, Társadalomtörténeti tanulmányok, 198, 202.

43 Benda, Társadalomtörténeti tanulmányok, 195.

44 Ljungqvist et al., "The Significance of Climate Variability."

45 Kövér, “A piacgazdaság kiteljesedése," 349-50.
} 
The transformation of the Great Hungarian Plain's economy continued in the first half of the nineteenth century: livestock farming was gradually replaced by arable crop production. The major boost for the transformation, however, was given by the appearance of the railway and the launch of comprehensive water regulation. Prior to industrial modernization, the crops produced within the terrain were collected and forwarded towards the mountain regions by the towns located at the edges of the region along the market line, such as Košice (Kassa), Berehove (Beregszász), Oradea (Nagyvárad), Arad, or Timişoara (Temesvár). These centers were surrounded by a second and a third circle in a concentric circle of centers around the Great Hungarian Plain. ${ }^{46}$ This system ensured the grain supply within the Carpathian Basin during the Modern Era and at the beginning of modern times. The system was strongly influenced by the size of the market center vicinities, which continued to be a major factor up to the beginning of the twentieth century, ${ }^{47}$ particularly in terms of industrialization and locating new industrial plants. ${ }^{48}$ The centers/towns with an extended vicinity were important hubs for the transit going through them, thus they managed to maintain their leading role in the region of the Great Hungarian Plain.

It is visible that the grain boom made a fundamental impact on the emergence of the urban system in the Great Hungarian Plain. The reason why grain boom seems to have been of such major significance for the various structures in it is because, already at the turn of the eighteenth-nineteenth centuries, trading in crops in the Carpathian Basin had been integrated into the continental system. The varied regional infrastructure of the grain trading network, accompanied by the town system stemming from this network, provided the frames for the huge grain boom in the nineteenth century. In this context, the role the market centers and the innumerable homesteads dotting the Great Hungarian Plain played in the transition of the economic structure should be viewed from a different perspective, and should be attributed more complex meanings.

\section{The impact of changes in economic structure on the urbanization of the Great Hungarian Plain}

Livestock farming was characteristic of the Great Hungarian Plain up to the mid-nineteenth century, ${ }^{49}$ while - due to the unfavorable transportation conditionsthe region, whose population was growing, still had to produce the necessary amount of grain locally. From the 1790s, the process was helped by a permanent decrease in

46 Glósz, Gabonakereskedelem Magyarországon, 241-52.

47 Szilágyi, "Az alföldi piacközpont-állomány változása."

48 Katona, Az Alföld gazdasági jövője, 16-7.

49 Orosz, Tanulmányok, 15. 
rainfall ${ }^{50}$ and the related shrinking of water-prone areas, because this provided more crop ploughlands in the low-lying Central and Southern-Transtisza regions. At the same time, in the higher lying region between the Danube and the Tisza, further measures were taken to bind quicksand via planting vineyards and fruit trees. Thus, climate change resulted in diverse outcomes and environmental modifications in the different regions of the Great Hungarian Plain. Consequently, in the course of economic and social adaptation, the emergence and expansion of homesteads in the Great Hungarian Plain were also induced by various causes.

The expansion of homesteads contributed to a rise in the population of the external territories, while internal population numbers were starting a (temporary) decrease. It is estimated that at the beginning of the nineteenth century, tens of thousands of people were already living on homesteads in the Great Hungarian Plain. ${ }^{51}$ By the 1870 s the region was inhabited by 200,000 citizens, and by 1920 there were more than one million homestead dwellers. ${ }^{52}$ The fact of large masses moving out of towns and villages had a partly favorable effect by mitigating internal social tensions. Via their workforce supply, these newly migrating people contributed to changing the factors and conditions of agricultural activity in the fields. (For a deeper understanding of changes in how the borderland was utilized in the nineteenth century, further study is needed.). ${ }^{53}$

After 1850, the railway revolutionized passenger and cargo transportation in the Carpathian Basin. With reference to Pál Beluszky's concept, it is obvious that there is a correlation between having the railway and economic prosperity, modernization, and urbanization. ${ }^{54}$ Naturally, it was much easier to construct a railway network in a flat terrain with beneficial geographical conditions than in a mountainous terrain; thus the development of the railway system saw reasonable acceleration. ${ }^{55}$ For the sake of protecting this linear infrastructure, speeding up water regulation was also necessary. ${ }^{56}$ Although following the endeavors of István Széchenyi (1791-1860), ${ }^{57}$ water regulation used to be regarded as an issue of social welfare,

50 Rácz, “A kis jégkorszak éghajlati változásainak hatása," Fig. 1.

51 See Beluszky, Magyarország településföldrajza, 99.

52 Faragó, Bevezetés, 274.

53 Balogh, "Határhasználat Hajdúböszörményben, 1"; Balogh, "Határhasználat Hajdúböszörményben, 2"; Balogh, "Határhasználat és gazdálkodás Nyíregyházán”; Molnár, "Határhasználat”; Molnár, "Nagyrábé népének gazdálkodása”; Novák, A három város, 181-285; Novák, A Három Város néprajza, 405-542; Papp, Biharország jobbágynépe, 45-96; Orosz, Tanulmányok, 55.

54 Beluszky and Győri, Magyar városhálózat, 57.

55 Katus, “A szállítás forradalma”; Katus, “Szállítási forradalom Magyarországon”; Majdán, "Magyarország közlekedése."

56 Lászlóffy-Böhm, "A Tiszavölgy”; Botár and Károlyi, A Tisza szabályozása (1848-1879); Botár and Károlyi, A Tisza szabályozása (1879-1944); Ihrig et al., A magyar vizszabályozás története. 
it has recently been established that water regulation was also in the interests of the Transtisza landowner nobility. ${ }^{58}$ But the start of water regulation in the Great Hungarian Plain was not merely due to these causes, but also to the construction of the railway network, and after a while, its required maintenance further assisted the process. Meanwhile in the background, another issue was gradually transpiring, namely the risks of climate change that the population increasingly frequently faced, which the political elite was trying to abuse for their own purposes. Additionally, some had a vested interest in utilizing the advantageous effects of the grain boom due to the stepped up demand for food by Western Europe's growing population. As a result, the size of lands under cultivation saw a rapid growth during the second half of the nineteenth century, for which water regulation was a vital element.

Remote European markets came within easy access by rail, which accelerated further the ongoing economic structural switch. The joint effects of remarkable investments in the Great Hungarian Plain adjusted to the extended European grain boom, the construction of the railway network, and the population buildup in the region triggered a process of modernization and urbanization that differed from processes taking place elsewhere in the Carpathian Basin. These structures gave the background to various regionally differentiated transitions. Prior to the railway constructions and during the preindustrial period, they had been affected by climate change to a higher degree than during later times.

The Great Hungarian Plain's modernization, a notion which is hard to define, involved multiple developments at the same time. It meant the expansion of cargo and passenger transport, the economic boost given by investments in water regulation, and also implied the transformation of the settlement network related to climate change and water regulation. These were the network structures that became the spheres of modernization. These 'corridors' and 'junctions' enabled the masses to move, bringing about the 'critical population density'. Since modernization requires a level of population density, it is worth taking the different forms of concentration into consideration. In the nineteenth century, besides the Great Hungarian Plain's population density, its cargo and passenger transport network, as well as the settlements' (towns and homesteads) own density also saw a rise. In turn, the dynamic surge in the number of interactions in traffic and telecommunications at the end of the century induced further changes. Up to the turn of the century, the urbanization of the Great Hungarian Plain depended on, among other factors, these processes.

The population of the Great Hungarian Plain soared remarkably in the towns and the peripheries. Consequently, both towns and homesteads were scenes of modernization in the Great Hungarian Plain. As we have seen, grain trade seems to have 
played the crucial role in the region's urbanization. The market centers provided the internal (regional) settlement network junctions. The emergence of the network presented a particular picture: in the first half of the nineteenth century the bigger trading centers on the edge of the region were the decisive elements of the settlement network. The formation of the network within the internal territories accelerated only in the second half of the century via the growing density of railway lines and via the establishment of civil local administration. This process was defined by the (new) market centers in the Great Hungarian Plain which, in most cases, were surrounded by narrowing catchment areas. The growing population density is reflected in the network buildup, as between 1828 and 1925, the number of these centers grew elevenfold (Tab. 1). ${ }^{59}$ This process was not only linked to the surging population's growing food demand, but also correlates with the modified consumer habits of society in the Great Hungarian Plain (Tab. 2). This gradually evolving high density may be presumed to have been the basis of the dynamic development of the Great Hungarian Plain up to the turn of the nineteenth-twentieth centuries. ${ }^{60}$ In addition to "market centralization", the region's urbanization was also determined by the fact that as early as the sixteenth-seventeenth centuries the population had already crowded into market towns.

Table 1 Changes in the number of market centers in the Great Hungarian Plain in 1828-1925

\begin{tabular}{|c|c|c|c|c|c|}
\hline \multirow[b]{2}{*}{ Market center } & \multicolumn{2}{|c|}{1828} & \multicolumn{2}{|c|}{1925} & \multirow{2}{*}{$\begin{array}{l}\text { Rate of growth } \\
6.6 \text {-fold }\end{array}$} \\
\hline & 11 & $40.7 \%$ & 73 & $24.9 \%$ & \\
\hline Market subcenter & 15 & $55.6 \%$ & 62 & $21.2 \%$ & 4.1-fold \\
\hline Self-sufficient market center & 1 & $3.7 \%$ & 158 & $53.9 \%$ & 158.0-fold \\
\hline Total & 27 & $100.0 \%$ & 293 & $100.0 \%$ & 10.9-fold \\
\hline
\end{tabular}

Source: Bácskai and Nagy, Piackörzetek, 45-51; ATTA

Table 2 Changes in the population of market centers in the Great Hungarian Plain in 1828-1920/1925

\begin{tabular}{|l|l|l|l|l|l|}
\cline { 2 - 6 } \multicolumn{2}{c|}{} & \multicolumn{2}{l|}{1828} & \multicolumn{1}{l|}{$1920 / 1925$} & Rate of growth \\
\hline Market center & 247,941 & $72.4 \%$ & $1,970,976$ & $57.1 \%$ & 7.9 -fold \\
\hline Market subcenter & 89,240 & $26.1 \%$ & 706,563 & $20.5 \%$ & 7.9 -fold \\
\hline Self-sufficient market center & 5,088 & $1.5 \%$ & 773,215 & $22.4 \%$ & 152.0 -fold \\
\hline Total & 342,269 & $100.0 \%$ & $3,450,754$ & $100.0 \%$ & 10.1 -fold \\
\hline
\end{tabular}

Source: Bácskai and Nagy, Piackörzetek, 45-51; ATTA

59 Bácskai and Nagy, Piackörzetek; Szilágyi, “Az alföldi piacközpont-állomány változása.”

60 See Demeter, "Perifériák”; Pénzes, "Fejlettségi különbségek"; Szilágyi, A Kárpát-medence fejlettségi membránja. 
This dynamic development and the transformation of the society and its economy continued as long as the bases of the system of operation were stable. By the end of the nineteenth century, however, both the development of the continental economic background and the modernization (network) of the Great Hungarian Plain had slowed down. From the point of view of the region, this was because river regulation activities as well as the expansion of the railway network had been completed by the beginning of the twentieth century. The economic structure that switched from free-range livestock farming to grain production could ensure economic growth, as it had been the general practice earlier, only as long as additional pieces of land could always be brought in as ploughlands for cultivation. However, from the turn of the nineteenth-twentieth centuries, the sustainability of extensive economic growth was no longer a possibility, as no land of remarkable size had remained for this purpose. At this point, the growth ensured by the Great Hungarian Plain's economic structure reached its limits, thereby generating another structural crisis.

The signs of the crisis were not clearly apparent because the Great Hungarian Plain's economic structure operated on the basis of regional differences. In the homesteads around the market towns in the region between the Danube and the Tisza, a new economic symbiosis was taking shape. ${ }^{61}$ The town - homestead relationship enabled a new trajectory of economic development, namely capital accumulation in peasant farmlands, creating thereby novel forms of rural urbanization and embourgeoisement. Although the process was triggered by the adaptation of settlements and their social and economic setups to the newly emerging environment due to climate change, the engine of the shift was the unprecedented population growth in the capital from the 1870s onwards. The new economic hinterland that was to meet the rocketing food demand of the population of Budapest was located mainly in the Great Hungarian Plain and in the region between the Danube and the Tisza. This in turn greatly contributed to the emergence of the terrain's internal differences in terms of their economy and development, as well as to its long-term conservation.

It was another significant contribution to the dynamic development of the Great Hungarian Plain that the terrain's economic structure required employing more living labor rather than mechanization. ${ }^{62}$ Consequently, besides involving additional lands for ploughing, the dynamics of development remained sustainable as long as the terrain had a capacity for sustaining the incoming population. This concept also implies that the modernization of the Great Hungarian Plain and the engine of sustainable economic development was not only the new settlement network (transition to homesteads and market centers) but also the provision of workforce flow, and the maintenance of undisturbed cargo and passenger railway transport.

61 Szilágyi, Város-tanya kapcsolat.

62 Orosz, Tanulmányok, 18. 
This sensitive balance was upset by several simultaneous processes in the last third of the nineteenth century. Beyond the changes described above, the transformation of the continental economic structure and the region's failure to be integrated into the global word economy all contributed greatly to the emergence of the problems. The economy of the Great Hungarian Plain produced goods that were becoming less and less, or not at all, competitive in the global market. This trend is well-demonstrated by the fact that the grain produced in the Great Hungarian Plain was uncompetitive with overseas produce as early as the 1870s. The Government of the Monarchy wished to mitigate this market effect by ensuring the undisturbed cargo transport and inland grain trade within the customs borders of the Monarchy. That way a specific, temporarily efficient internal market was established, which however had the serious consequence that this market gradually fell behind the global economy. ${ }^{63}$ The economic structure of the Great Hungarian Plain became obsolete and unsustainable within the given frames. Due to the fact that no comprehensive developments affecting the entire terrain were happening and only private investments were made in certain localities, not only the competitiveness (diversity) of the terrain was endangered but also the process of pushing some sections to the peripheries of the terrain was intensified. ${ }^{64}$ To make matters worse, by the turn of the century, mobility opportunities for the population linked to the modernization of the Great Hungarian Plain were tangibly more limited.

Because migration within the Carpathian Basin had new destinations (overseas emigration), ${ }^{65}$ modernization slowed down, thus one of the main drivers of dynamic development (internal migration) lost its momentum. Despite the emigration rate and the intensifying migration away from the Great Hungarian Plain, at the beginning of the twentieth century it was still a destination for a major part of incoming migrants, ${ }^{66}$ which concealed the majority of the problems originating from the looming crisis of the economic structure.

As opposed to the trends highlighted so far, during the industrial era, another climate change within the Carpathian Basin also greatly contributed to the economic structural crisis of the Great Hungarian Plain (after 1850). As during the earlier climate period the water protection infrastructure had been adjusted to lower levels of rainfall, the higher number of floods from the 1870s posed new challenges ${ }^{67}$ The costs of additional investments were not compensated by income from the sale of

63 Orosz, Tanulmányok.

64 Pénzes, "Fejlettségi különbségek."

65 Rácz, “A parasztok elvándorlása”; Puskás, “Kivándorlás Magyarországról”; Puskás, Kivándorló magyarok; Beluszky, “Az ország lakói,” 211, 228-39; see Kovács, A kivándorlás.

66 Szilágyi, "Vándormozgalom."

67 Rácz, A kis jégkorszak éghajlati változásainak hatása, Fig. 1. 
farmland produce (and the situation was aggravated by the lack of competitiveness explained above). ${ }^{68}$ The fact that the period of grain production was more humid had a negative effect on average yields and the market price of crops. The situation was worsened by the failure to implement investments due to their high costs. Consequently, the inland water drainage system could not be constructed where the original aim was not to drain surface waters. Thus, in the riverside areas that were converted into ploughlands, where the inland water drainage system was missing, there was an increasing danger of inland inundation during rainy periods, and inland water caused more frequent damage. These factors cumulatively intensified the crisis of the economic structure in the region of the Tisza and its tributaries. The regionally emerging, mostly self-sufficient market centers without significant catchment areas (önforgalmú piacközpontok) ${ }^{69}$ could no longer be the country "bridgeheads" of modernization. In their vicinity, embourgeoisement slowed down.

In parallel, the excess rainfall acted as a stimulus in the formerly quicksand surfaced areas, where owners of freshly planted vineyards and orchards, as well as traders benefitted from the change in the climate. The societies of these regions, however, embarked on a different route, offering different ways of rural embourgeoisement, capital accumulation and social mobility. In the region between the Danube and the Tisza, market towns with associated homesteads emerged as the new central areas in place of the previous market towns on the edges of the Great Hungarian Plain. These towns, besides the more significant Transtisza market towns, turned out to be the centers of modernization in the Great Hungarian Plain, whose transition was greatly shaped by the economic damage of the Phylloxera plague in the last third of the nineteenth century.

\section{Diversification: the effect of the Phylloxera pest on the urbanization of the Great Hungarian Plain}

Based on earlier reports, the first European areas infected by the grapevine root Phylloxera were recorded in France in the second half of the 1860s. The infection spread towards Portugal, Austria, Germany, Switzerland and reached Hungary in 1875. In the Carpathian Basin, the first region to suffer from the presence of the pests was Pančevo (Pancsova). Before the end of the decade, the infection was observed only in a few dozen municipalities. After that point, however, the plague was spreading extremely rapidly. In 1890 , nearly 2,000 settlements were affected,

68 Demeter, A Balkán, 83.

69 See Szilágyi, “Az alföldi piacközpont-állomány változása,” 206, 218-22; and Szilágyi, “Az 1925. évi közigazgatási tájékoztató lapok.” Self-sufficient market centres were settlements that identified themselves as market centres but other villages did not. 
totaling 16 percent of the settlements in the Carpathian Basin. The infection first occurred in isolation, mainly in the vicinity of busy centers like on the peripheries of Košice, Berehove, and Satu Mare (Szatmárnémeti). In the 1880s, the vine root pests spread in all the vine growing regions of the Carpathian Basin, infecting vast uninterrupted areas. The infection also affected the entire Transdanubia and the Northern Hungarian Uplands from Nagykanizsa to Sátoraljaújhely, in addition to the entire Bihar and Békés Counties, the Sălaj (Szilágyság) and Banat. ${ }^{70}$

The transmission of pests was greatly enhanced by human presence. Unaware of the danger, people carried them on their clothes or often on the surface of agricultural tools from one spot to another. This explains in retrospect why the Great Hungarian Plain, mainly the Central and Southern-Transtiszaninan crop lands, where arable farming was typical, was affected similarly to mountainous terrains. In this case, the epicenter of the infection must have been the Nagykunság. The other focal points seem to have been located outside the region: in the late 1870s, the presumable centers were areas of Bihar County, the Szilágyság and Gemer (Gömör). ${ }^{71}$

Based on these records, the region of the Great Hungarian Plain split into two parts: a heavily uninfected one including the region between the Danube and the Tisza, and the Northern-Transtisza (Nyírség) areas; and the infected part including the Central and Southern-Transtisza regions. The uninfected areas were the sandy soils of the Great Hungarian Plain, where the sand proved to be immune to the vine root pest infection. Among the reasons why the Phylloxera could spread in the rest of the Great Hungarian Plain was that those territories were not covered by sand, and the farmlands there usually had vineyards with weak yields, producing wine for the peasants' own consumption. Another reason was that the seasonal workers who would come to plough the lands arrived from the already infected mountains nearby.

The Phylloxera infection temporarily divided the Great Hungarian Plain into two, which had remarkable economic and social consequences by the beginning of the twentieth century. In this temporary phase, the towns in the region between the Danube and the Tisza gained economic advantages over the TranszTisza centers. This short-lived beneficial period was enough for the region's economic structural transition to speed up. The process was enhanced by the capital's population boom: in 30 years the number of its inhabitants went up by $450,000 .{ }^{72}$ At the same time, its food demand doubled or tripled, which had to be satisfied mainly by the (peasant) farms of the region between the Danube and the Tisza. It was at this time that the numerous homesteads surrounding the region's bigger towns switched to

70 Horváth, "Filloxera," 194-6.

71 Horváth, "Filloxera," 194-5.

72 A magyar korona országaiban az 1870. év elején végrehajtott népszámlálás, 69; A magyar korona országainak 1900. évi népszámlálása, 200. 
intensive garden cultivation. In consequence, the majority of the medium and large owners and tenants of homesteads lying in the vicinity of towns ran up large debts. The economic structural transition was also accelerated in the region between the Danube and the Tisza by the natural landscape conversion induced by the moving sand and anthropogenic landscape modifications. Profound changes in land use (i.e., stopping livestock farming) meant further advantages in a situation where, due to the Phylloxera infection, the hub of vine production was relocated to the immune sandy areas. This opportunity may seem to have been open to the sandy Nyírség as well, but it was unfortunately missing some of the additionally required factors. On the one hand, the region was lacking in towns (i.e., in market centers) ${ }^{73}$ having no dynamically growing city like Budapest nearby with an increasing population and a market to purchase their produce. On the other hand, the economy of the Nyírség was unable to grow dynamically because the human resources available in the region were less favorable than those of the region between the Danube and the Tisza. ${ }^{74}$

Between the Danube and the Tisza the slow process of planting vines and fruit trees, which had been going on for centuries, was accelerated from the 1880s, especially in the region of the three towns, namely Kecskemét, Nagykörös, and Cegléd. ${ }^{75}$ The city council of Kecskemét, for instance, added to the external areas of the settlement via land purchases. The sandy land ideal for vine plantation continued to be inexpensive even though the vine decay in the mountains led to certain price rises. It was a wise investment for the town to purchase these parcels, which it later portioned out to its residents. The lease generated further income for the town, while the community was given the possibility of accumulating wealth, thus the transition of peasant communities (embourgeoisement) also went into a higher gear. Vegetable and fruit production widespread on lands of lower quality contributed to the region's capacity to supply first the needs of nearby markets, and later, at the turn of the century, to cater for remote export markets. Trade with distant buyers profoundly transformed the economy and society of the three towns-representing a special path to urbanization in the Great Hungarian Plain. The centers of Cegléd and Nagykörös and, in particular, the center of Kecskemét went through rapid urbanization. The stylistic features of Art Nouveau appearing in their built environment reflected the local elites' strong mental and economic link to the elites countrywide, especially the upper-class world of the capital. ${ }^{76}$

73 Szilágyi, "A térinformatika," 34-6.

74 Szilágyi, "A fejlettség területi különbségei”; Szilágyi, "A Kárpát-medence fejlettségi membránja”; Szilágyi, "Az életminőség területi egyenlőtlenségeinek változása”; Szilágyi, "Regional Differences."

75 See Novák, A három város; Novák, A Három Város néprajza.

76 Szilágyi, Föld és hatalom, 104. 
The basis of economic growth for the towns in the region between the Danube and the Tisza was the strong unity between homesteads and market town centers. In fact, in the last third of the nineteenth century, homesteads meant economic modernity in the Great Hungarian Plain. Due to changes in land use, the revolution of cargo transportation, and to the opening up of export markets, capital accumulation was (also) accelerated within the region. Naturally, these factors exerted their influence on wealth retention and consumer habits. In the emerging new social medium, diverse cultures and religions lived well side by side with each other, even in the interwar period. Undoubtedly, the region between the Danube and the Tisza was regarded as an economic hub for long decades. Accordingly, human resources available were also of remarkably high quality in the area, whose population was characterized by considerable mobility and migration. The Great Hungarian Plain was one of the main targets of migration in the first half of the twentieth century, and continued as such when, after 1920, the structure and directions of migration underwent fundamental changes. ${ }^{77}$

In contrast, starting from the 1880 s and 1890 s, the Transtisza town belt ${ }^{78}$ was continuously losing its economic dynamism, and by the turn of the century, the speed had very considerably slowed down. This region followed a different trajectory to urbanization. The landscape went through significant transformations due to climate change and, even more explicitly, due to water regulation. The wetlands necessary for livestock farming were shrinking, and with the course of time, they completely disappeared. The former floodplains and marshlands were replaced by arable land. The traditional employment structure was disappearing. Several of the national writers clearly saw and described the process as rapid pauperization. ${ }^{79}$ At the turn of the century, the Transtisza society faced severe financial difficulties. When river regulation was completed, the diggers were left without work. Some of the unemployed were trying to find jobs in nearby or remote towns, others decided to emigrate. Only from the Great Hungarian Plain, more than a quarter of a million citizens emigrated, trying their fortune mainly overseas, however, almost 60 thousand returned already before World War I. ${ }^{80}$

The situation for the Transtisza society was further worsened by the fact that the supplementary infrastructure to water regulation was not completed, for example the groundwater drainage system, although the period between 1880 and 1940 was

\footnotetext{
77 Szilágyi, "Vándormozgalom.”

78 Szilágyi, "Alföldi vonzáskörzetek," 118.

79 Veres, Az Alföld parasztsága; Féja, Viharsarok; Nagy, Tücsök a máglyán; Papp, A magyar népi mozgalom, 91-124.

80 Szabó, Két és fél évszázad, 119.
} 
definitely humid. ${ }^{81}$ Later, these missing investments contributed to the emergence of the periphery in the Transtisza region. The reason why there was no financing for the investments was partly that by the time the new economic structure was established in the Great Hungarian Plain, and by the time the switch from livestock and floodland farming to grain production via the expansion of arable land had been done, in Europe both the grain boom and the demographic transition had turned into a slowdown period. Moreover, a new situation emerged in the continental markets due to the appearance of cheap crops from overseas. As a consequence, more than three quarters of the crops mainly produced in the Great Hungarian Plain ${ }^{82}$ was delivered to the internal market of the Monarchy already in the $1880 \mathrm{~s} .{ }^{83}$ At the same time, production was via traditional methods, utilizing manual workforce at a high rate, and machinery at a low rate. Although grain and flour were continuously marketable (even to a growing extent!) in the internal markets, outside the country they were not competitive.

The economic structure of the Transtisza region-especially after the Phylloxera plague-continued to be a monoculture where the major role was attributed to arable grain production, thus these regions were exceptionally vulnerable to economic crises. Diversified production was missing in the Transtisza farm estates. This vulnerability was strengthened by the fact that due to the incomplete infrastructural investments, the growing rate of rainfall regularly caused inland water damage. Moreover, the region had to face a formerly unknown problem: secondary salinization.

\section{Moving further: possible alternative interpretations of the socio- economic processes in the interwar years}

The homesteads in the Great Hungarian Plain, which in the nineteenth century had typically been hubs of advancement and symbols of modernization, by the beginning of the twentieth century had often turned into images of underdevelopment and numerous educational, health, and social problems. ${ }^{84}$ How did this happen? The question highlights that the expansion of the homesteads in the Great Hungarian Plain gave a socio-economic answer to the challenges at a time when climate change provided new opportunities for terrains sensitive to rainfall distribution, which were typical not only of the Great Hungarian Plain but of the entire continent. It is obvious that one of the central elements of economic structural transition was the homesteads. From the end of the eighteenth century, the structural transition

81 Rácz, A kis jégkorszak éghajlati változásainak hatása, Fig. 1.

82 Fodor, Magyarország gazdasági földrajza, 87.

83 Katus, “A Monarchia közös piaca," 126.

84 Czettler, Tanyai település. 
(livestock farming replaced by arable production) was faster, which revealed structural imbalances prior to the completion of the transition. By the end of the nineteenth century, a more humid climate, ${ }^{85}$ coupled with changing (global and continental) market conditions, placed the Great Hungarian Plain's economy, which was just undergoing its major structural formation, into a very different position. As homesteads were unable to adapt to these new changes, they became a visible site of the pauperization of the Great Hungarian Plain's society. The special structure and geographical position (located far from the centers) of homesteads were factors in themselves that made it difficult or almost impossible for homestead dwellers to join any of the networks. ${ }^{86}$ In the 1920 s, there were already more than one million people living in the Great Hungarian Plain's homesteads, ${ }^{87}$ which did not receive any of the infrastructural developments. Consequently, their economic, social, and cultural "isolation" was gradually becoming an everyday experience. Mitigating this cultural isolation was a priority for the homestead school program initiated by the influential politician Kuno Klebelsberg, as well as of a number of other efforts at setting up homestead hubs in the interwar period. Despite the negative trends outlined above, we may state that in the nineteenth century, homestead farms meant one of the important pillars of modernization in the Great Hungarian Plain. In the locations where the homesteads were present, capital accumulation, population growth, and urbanization were accelerated in the nearby market centers, as opposed to regions dominated by very small villages inhabited by low numbers of people. ${ }^{88}$

During the Great Hungarian Plain's modernization, one of whose priorities was water regulation, such lands were made arable that typically had low agriculturalecological potential. Sensitivity to drought accompanied by drying pastures were longterm consequences. ${ }^{89}$ The elements that meant profits and the possibility for capital accumulation and citizenship transition in the short run, within the given frames, meant obstacles to "economic development" and to the sustainability of economic development in the long run. The anthropogenic environmental transition led not just to the deconstruction and transformation of the traditional ecosystem of the landscape within a couple of decades, but also profoundly decreased the diversity of species living in the water habitats of the Great Hungarian Plain. These developments happened simultaneously with the expansion of monocultural plant production mainly in the Tisza-valley and TranTisza area, also resulting in the shrinking of the unspoilt "wild

85 Rácz, A kis jégkorszak éghajlati változásainak hatása, Fig. 1.

86 See Barabási, Behálózva.

87 Faragó, Bevezetés, 248; Thirring, “A tanyák,” 1050; see Weis, Mai magyar társadalom, 12.

88 Szilágyi, “A fejlettség területi különbségei," 90.

89 Pinke, Alkalmazkodás és felemelkedés, 136. 
nature". ${ }^{90}$ The Great Hungarian Plain, including its economy and society, had become more sensitive to catastrophes, which had its consequences felt in sustainable development and urbanization within the region. (This is despite the fact that undoubtedly this extensive formation/conversion of the terrain and the homogenized landscape use made modernization and its acceleration in the Great Hungarian Plain possible under the conditions ensured by the era.) Based on this, the Great Hungarian Plain around the turn of the nineteenth-twentieth centuries seems to reflect a slowing down of economic momentum and signs of another looming economic structural crisis. The homesteads located near the formerly often flooded self-sufficient market centers with limited economic-trading contacts, ${ }^{91}$ and the ones near former floodplain zones ensured less and less favorable living conditions for their residents. In contrast, the homesteads situated near centers where trade was expanding, differentiated trading roles were forming, and where they also produced goods for international markets, were characterized by favorable conditions. These homesteads showed a new type of adaptation: a diversified production structure and intensive garden cultivation. After 1920, many authors considered these features to be the pillars of a future agricultural economy, the concept of "gardened Hungary" ${ }^{2}$ It was a specific constellation of circumstances that enabled the emergence of these "gardened homesteads". A major role may be attributed to the advantageous features of sandy soils (e.g., immunity towards Phylloxera, or the region's higher albedo rate, which resulted in tastier and more saleable fruits produced in the region and delivered to other markets). ${ }^{93}$ I would argue that it was the economic symbiosis between the homestead and the town that made the delayed blooming between the two world wars possible for market towns in the Great Hungarian Plain, especially for those in the plain between the Duna and the Tisza.

However, the problems of the Great Hungarian Plain's economic structure formed by the end of the nineteenth century, as well as the grave consequences of anthropogenic landscape conversion were concealed by the warfare boom in the 1910s. It follows that Trianon was not the single cause of the economic recession after the loss of the war. ${ }^{94}$ After 1920 , certain problems came to the surfaced that had already been present at the turn of the century in the Great Hungarian Plain, but then few people had noticed them. ${ }^{95}$ Under the given conditions, the economic growth of the terrain became unsustainable. What is more, it is probable that there

90 See Attenborough and Hughes, Egyélet a bolygónkon, 202-20.

91 See Szilágyi, “Az alföldi piacközpont-állomány változása,” 206, Fig. 3; Szilágyi, “Az életminőség," 301, Fig. 23; Szilágyi, "Regional Differences," 133, Fig. 4.

92 Móricz, “A magyar gyümölcs,” 244; Németh, Kisebbségben, 90; Somogyi, Kertmagyarország felé.

93 Szilágyi, Homokváros, 63.

94 Szilágyi, "Alternatív Trianon.”

95 Czettler, Tanyai település; Katona, Az Alföld gazdasági jövője. 
was some relative overpopulation as well in certain regions of the Great Hungarian Plain, which is indirectly reflected in the start of inland migration within the country. Three quarters of the settlements in the Great Hungarian Plain produced population growth directly prior to the World War I; one third, however, suffered such a high rate of population loss that they lost at least a tenth of their residents or, in certain cases, up to half of the their population..$^{96}$ There is no doubt that this process fundamentally influenced urbanization in the Great Hungarian Plain. ${ }^{97}$

Finally, I wish to emphasize that the concentration of the human resource capital in the Great Hungarian Plain (significantly more advantageous than in the whole of the Carpathian Basin) and its multi-centered development structure-which had come about by the turn of the century-made a fundamental contribution to the surprisingly rapid "economic reconstruction" of Hungary following the 1920 Trianon Treaty. ${ }^{98}$ Despite the slowing down of modernization and urbanization in the Great Hungarian Plain, the accumulated economic momentum gained during the former decades could still ensure a for a shorter period of time a "balanced" background for the economic, social, and political transition in the 1920s. The higher level of development of the Great Hungarian Plain compared to conditions within the Carpathian Basin that emerged by the beginning of the twentieth century was undoubtedly utilized by the society of post-Trianon Hungary, including the political elite. Nevertheless, no extensive economic investments were made to support the structural transition in the Great Hungarian Plain. One of the reasons was the lack of capital, accompanied by some other hurdles. It cannot be denied that the situation was not improved by contemporary political and other propaganda focusing on the losses of Trianon and revision. ${ }^{99}$ The "narrative of losses" concealed most of the similarly real economic and social problems of the time.

\section{Sources}

A magyar korona országaiban az 1870. év elején végrehajtott népszámlálás eredményei a hasznos házi állatok kimutatásával együtt [Census data in the Hungarian Crown-related countries at the beginning of 1870, including livestock numbers]. Pest: Országos Magyar Királyi Statistikai Hivatal and Athenaeum, 1871. A magyar korona országainak 1900. évi népszámlálása. A népesség általános leirása községenkint [The 1900 Census in the Countries of the Crown of

96 Szilágyi, "Vándormozgalom,” 97.

97 See Beluszky and Győri, Magyar városhálózat; Bán, "A magyar városhálózat hierarchiája."

98 Szilágyi, “A Kárpát-medence fejlettségi membránja," 79-80; see Tomka, Gazdasági növekedés, 86.

99 Zeidler, A reviziós gondolat. 
Hungary. General Description of the Population according to Municipalities]. Budapest: Magyar királyi Központi Statisztikai Hivatal, Pesti KönyvnyomdaRészvénytársaság, 1902.

ATTA - Alföldi Települések Történeti Adatbázisa [The Historical Database of

Settlements in the Great Hungarian Plain, by Zsolt Szilágyi, 2.2 million records]. For the sources and detailed description of the database see: Szilágyi, "Az alföldi piacközpont-állomány változása."

Pécsi, Márton, ed. Magyarország nemzeti atlasza [National Atlas of Hungary]. Budapest:MagyarTudományos Akadémia and Mezőgazdaságiés Élelmezésügyi Minisztérium, 1989.

\section{Literature}

Ágoston, Gábor and Teréz Oborni. A tizenhetedik század története [The History of the Seventeenth Century]. Budapest: Pannonica Kiadó, 2000.

Attenborough, David and Jonnie Hughes. Egy élet a bolygónkon: A szemtanú vallomása - és látomás a Föld jövőjérooll [A Life on Our Planet: My Witness Statement and a Vision for the Future]. Budapest: Park Könyvkiadó, 2020.

Bácskai, Vera and Lajos Nagy. Piackörzetek, piacközpontok és városok Magyarországon 1828-ban [Market Regions, Market Centers and Towns in Hungary in 1828]. Budapest: Akadémiai Kiadó, 1984.

Bácskai, Vera. Városok Magyarországon az iparosodás előtt [Cities of Hungary Prior to Industrialization]. Budapest: Osiris Kiadó, 2002.

Balogh, István. "Határhasználat és gazdálkodás Nyíregyházán a XVIII-XIX. században" [Land Use and Farming in Nyíregyháza in the $18^{\text {th }}-19^{\text {th }}$ Centuries]. Ethnographia 81, no. 2-4 (1970): 221-33.

Balogh, István. "Határhasználat Hajdúböszörményben a XVIII. században" [Land Use in Hajdúböszörmény in the $18^{\text {th }}$ Century; Part One]. Ethnographia 65, no. 3-4 (1954): 441-57.

Balogh, István. "Határhasználat Hajdúböszörményben a XVIII. században" [Land Use in Hajdúböszörmény in the $18^{\text {th }}$ Century; Part Two]. Ethnographia 66, no. 1-4 (1955): 99-124.

Bán, Gergely Károly. "A magyar városhálózat hierarchiája és térszerkezete a két világháború között" [The Hierarchy and Spatial Structure of the Hungarian Urban Network in the Interwar Period]. In Magyar Gazdaságtörténeti Évkönyv 2020: Hálózat és hierarchia [Yearbook of Hungarian Economic History 2020: Network and Hierarchy], edited by György Kövér, Ágnes Pogány, and Boglárka Weisz, 93-146. Budapest: Bölcsészettudományi Kutatóközpont and Hajnal István Alapítvány, 2020.

Barabási, Albert-László. Behálózva [Linked]. Budapest: Magyar Könyklub, 2003. 
Barta, János. A tizennyolcadik század története [The History of the Eighteenth Century]. Budapest: Pannonica Kiadó, 2000.

Beluszky, Pál. "Az ország lakói - Magyarország demográfiai képe a századfordulón"

[Country Citizens: The Demographic Overview of Hungary at the Turn of the Century]. In Magyarország történeti földrajza 1. [The Historical Geography of Hungary, vol. 1], edited by Pál Beluszky, 153-314. Budapest-Pécs: Dialóg Campus Kiadó, 2005.

Beluszky, Pál. A Nagyalföld történeti földrajza [The Historical Geography of the Great Hungarian Plain]. Budapest-Pécs: Dialóg Campus Kiadó, 2001.

Beluszky, Pál. Magyarország településföldrajza: Általános rész [The Settlement Geography of Hungary: General Overview]. Budapest-Pécs: Dialóg Campus Kiadó, 2003.

Beluszky, Pál and Róbert Győri. Magyar városhálózat a 20. század elején [The Hungarian Urban Network in the Beginning of the $20^{\text {th }}$ Century]. BudapestPécs: Dialóg Campus Kiadó, 2005.

Benda, Gyula. Társadalomtörténeti tanulmányok [Social Historical Studies], edited by Vera Bácskai, János Gyurgyák, and György Kövér. Budapest: Osiris Kiadó, 2006. Benda, Gyula. Zsellérből polgár: társadalmi változás egy dunántúli kisvárosban; Keszthely társadalma 1740-1849 [From Cottar to Citizen: Social Transition in a Transdanubian a Small Town; The Society of Keszthely in 1740-1849], edited by Katalin Fenyves and M. István Szijártó. Budapest: L'Harmattan, 2008.

Botár, Imre and Zsigmond Károlyi. A Tisza szabályozása. I. rész (1846-1879) [The Regulation of the Tisza, Part 1 (1846-1879)]. Budapest: Vízügyi Dokumentációs és Tájékoztató Iroda, 1971.

Botár, Imre and Zsigmond Károlyi. A Tisza szabályozása. II. rész (1879-1944) [The Regulation of the Tisza, Part 2 (1879-1944)]. Budapest: Vízügyi Dokumentációs és Tájékoztató Iroda, 1971.

Czettler, Jenő. Tanyai település és tanyai központok [Homestead Settlement and Homestead Centers]. Budapest: Stephaneum Nyomda Rt., 1913.

Dányi, Dezső. Az élet ára: Gabona és élelmiszerárak Magyarországon 1750-1850 [The

Price of Life: Grain and Grocery Prices in Hungary in 1750-1850]. Budapest: Központi Statisztikai Hivatal Könyvtár és Levéltár, 2007.

Demeter, Gábor. A Balkán és az Oszmán Birodalom 3: Társadalmi és gazdasági átalakulások a 18. század végétöl a 20. század közepéig (Szerbia, Macedónia, Bosznia) [The Balkans and the Ottoman Empire, vol. 3: Social and Economic Transitions from the End of the $18^{\text {th }}$ Century to the Mid-20 ${ }^{\text {th }}$ Century (Serbia, Macedonia, Bosnia)]. Budapest-Debrecen: Magyar Tudományos Akadémia Bölcsészettudományi Kutatóközpont, 2016.

Demeter, Gábor. "Perifériák és fejlett régiók a történeti Magyarországon (18901910)" [Peripheries and Developed Regions in the Historical Hungary in 
1890-1910]. In Területi egyenlötlenségek nyomában a történeti Magyarországon. Módszerek és megközelitések [Investigating Territorial Inequalities in Historical Hungary: Methods and Approaches], edited by Gábor Demeter and János Szulovszky, 145-94. Budapest-Debrecen: Magyar Tudományos Akadémia Bölcsészettudományi Kutatóközpont, Debreceni Egyetem Társadalomföldrajzi és Területfejlesztési Tanszék, 2018.

Dobrovolný, Petr, Anders Moberg, Rudolf Brázdil, Christian Pfister, Rüdiger Glaser, Rob Wilson, Aryan van Engelen, Danuta Limanówka, Andrea Kiss, Monika Halíčková, Jarmila Macková, Dirk Riemann, Jürg Luterbacher, and Reinhard Böhm. "Monthly, Seasonal and Annual Temperature Reconstructions for Central Europe Derived from Documentary Evidence and Instrumental Records since AD 1500." Climatic Change 101, no. 1 (2010): 69-107. doi.org/10.1007/ s10584-009-9724-x

Dóka, Klára. A Körös és Berettyó vízrendszer szabályozása a 18-19. században. Egy táj átalakulása [Water System Regulation of the Körös and Berettyó in the $18^{\text {th }}-19^{\text {th }}$ Centuries: The Transformation of a Landscape]. Gyula: Békés Megyei Levéltár, 1997.

Dövényi, Zoltán. “A migráció szerepe Magyarország 18. századi népességnövekedésében" [The Role of Migration in Population Growth in the $18^{\text {th }}$ Century in Hungary]. Történeti Földrajzi Közlemények 4, no. 3-4 (2016): 47-53.

Faragó, Tamás. Bevezetés a történeti demográfiába 1. [Introduction to Historical Demography, Part 1]. Budapest: Budapesti Corvinus Egyetem, 2011. Accessed 26 October 2021. https://dtk.tankonyvtar.hu/handle/123456789/7423

Féja, Géza. Viharsarok: az alsó Tiszavidék földje és népe 37 fényképfelvétellel [The "Storm Corner": The Land and the Population of the Lower Tisza Countryside in 37 Photographs]. Budapest: Athenaeum Kiadó, 1938.

Fodor, Ferenc. Magyarország gazdasági földrajza: a fóiskolai hallgatóság, a magyar gazdaközönség, közgazdák, iparosok és kereskedök számára [Economic Geography in Hungary. For College Students, Farmers, Economists, Crftsmen and Merchants]. Budapest: Franklin-Társulat Magyar Irodalmi Intézet and Könyvnyomda, 1924.

Für, Lajos. Kertes tanyák a futóhomokon. Tájtörténeti tanulmány [Homesteads with Joined Gardens on Quicksand: Study on Landscape History]. Budapest: Akadémiai Kiadó, 1983.

Glaser, Rüdiger and Dirk Riemann. "A Thousand-Year Record of Temperature Variations for Germany and Central Europe based on Documentary Data." Journal of Quaternary Science 24, no. 5 (2009): 437-49. doi.org/10.1002/jqs.1302. Glósz, József. Gabonakereskedelem Magyarországon a 19. század elsö felében [Crop Trading in Hungary during the first half of the $19^{\text {th }}$ Century]. Budapest: L’Harmattan Kiadó, 2014. 
Gyáni, Gábor. Az urbanizáció társadalomtörténete: Tanulmányok [The Social History of Urbanization: Studies]. Cluj-Napoca: Korunk Komp-Press, 2012.

Hershberg, Theodore. "The New Urban History. Toward an Interdisciplinary History of the City." Journal of Urban History 5, no. 1 (1978): 3-40.

Horváth, Géza. "Filloxera" [Phylloxera]. In A Pallas Nagy lexikona: az összes ismeretek enciklopédiája tizenhat kötetben, Vol. 7 [The Great Lexicon of Pallas], edited by Lajos Gerő and József Bokor. Budapest: Pallas Irodalmi és Nyomdai Részvénytársaság, 1894.

Ihrig, Dénes, Zoltán Károlyi, Zsigmond Károlyi, and Ádám Vázsonyi. A magyar vízszabályozás története [The History of Water Regulation in Hungary]. Budapest: Országos Vízügyi Hivatal, 1973.

Iványosi-Szabó, Tibor. Kecskemét gazdasági fejlödése 1700-1850 [The Economic Development of Kecskemét in 1700-1850]. Kecskemét: Bács-Kiskun Megyei Önkormányzat Levéltára, 1994.

Katona, Béla. Az Alföld gazdasági jövője [The Economic Future of the Great Hungarian Plain]. Budapest: Légrády Testvérek Nyomdája, 1914.

Katus, László. "A szállítás forradalma" [The Revolution of Transportation]. In Magyarország története tíz kötetben 6/2. Magyarország története 1848-1890 [The History of Hungary in Ten Volumes, Part 6/2: The History of Hungary between 1848-1890], edited by László Katus, 976-87. Budapest: Akadémiai Kiadó, 1979.

Katus, László. “Szállítási forradalom Magyarországon a 19. században” [Transportation Revolution in Hungary in the 19 ${ }^{\text {th }}$ Century]. In Sokszólamú történelem: Katus László válogatott tanulmányai és cikkei [Poliphonic History: Selected Studies and Articles by László Katus], edited by Mariann Nagy and Lázár Vértesi, 134-42. Pécs: Pécsi Tudományegyetem Bölcsészettudományi Kar Történelem Tanszékcsoport, 2008.

Katus, László. “A Monarchia közös piaca” [The Common Market of the AustroHungarian Monarchy]. In Sokszólamú történelem: Katus László válogatott tanulmányai és cikkei. [Poliphonic History: Selected Studies and Articles by László Katus], edited by Mariann Nagy and Lázár Vértesi, 119-33. Pécs: Pécsi Tudományegyetem Bölcsészettudományi Kar Történelem Tanszékcsoport, 2008.

Kern, Zoltán. “Éghajlati és környezeti változások rekonstrukciója faévgyűrűk és barlangi jég vizsgálata alapján” [Climate and Environmental Changes Reconstructed from Tree Rings and Cave Ice]. PhD diss., Eötvös Loránd University, 2010. Accessed 26 October 2021. http://teo.elte.hu/minosites/ertekezes2010/kern_z.pdf. Kovács, Imre. A kivándorlás [Emigration from Hungary]. Budapest: Cserépfalvi Könyvkiadó, 1938.

Kováts, Zoltán. “A Kárpát-medence népesedési viszonyainak alakulása (900-1870)” [The Development of Population Growth Rates in the Carpathian Basin in 900-1870]. In Történeti Demográfiai Évkönyv 2001 [Historical Demographic 
Yearbook 2001], edited by Tamás Faragó and Péter Öri, 121-27. Budapest: KSH Népességtudományi Kutatóintézet, 2001.

Kováts, Zoltán. "A népességfejlődés vázlata a honfoglalástól 1920-ig" [An Outline of Population Development from the Hungarian Conquest to 1920]. In Az Alföld történeti földrajza [The Historical Geography of the Great Hungarian Plain], edited by Sándor Frisnyák, 129-41. Nyíregyháza: MTA Szabolcs-Szatmár-Bereg Megyei Tudományos Testülete, and Níregyházi Főiskola Földrajzi Tanszéke, 2000. Kövér, György. "A piacgazdaság kiteljesedése" [The Accomplishments of Market Economy in Hungary]. In 19. századi magyar történelem 1790-1918 [The History of the $19^{\text {th }}$ Century between 1790-1918], edited by András Gergely, 343-74. Budapest: Korona Kiadó, 1998.

Kövér, György. A tiszaeszlári dráma: Társadalomtörténeti látószögek [The Drama of Tiszaeszlár: Scopes of Social History]. Budapest: Osiris Kiadó, 2011.

Lászlóffy-Böhm, Woldemár. "A Tiszavölgy: Vízrajzi leírás és a vízmunkálatok ismertetése" [The Valley of Tisza: Hydrographic Description and Introduction of Water Regulation Works]. Vízügyi Közlemények 14, no. 2 (1932): 108-42.

Ljungqvist, Fredrik Charpentier, Andrea Seim, Paul J. Krusic, Jesús Fidel GonzálezRouco, Johannes P. Werner, Edward R. Cook, Eduardo Zorita, Jürg Luterbacher, Elena Xoplaki, Georgia Destouni, Elena García-Bustamante, Camilo Andrés Melo Aguilar, Kristina Seftigen, Jianglin Wang, Mary H. Gagen, Jan Esper, Olga Solomina, Dominik Fleitmann, and Ulf Büntgen. "European Warm-Season Temperature and Hydroclimate 850 CE." Environmental Research Letters 14, no. 8 (2019). doi.org/10.1088/1748-9326/ab2c7e.

Ljungqvist, Fredrik Charpentier, Peter Thejll, Bo Christiansen, Andrea Seim, Claudia Hartl, and Jan Esper. "The Significance of Climate Variability on Early Modern European Grain Prices." Cliometrica - Journal of Historical Economics and Econometric History 15, no. 2 (2021). doi.org/10.1007/s11698-021-00224-7

Luterbacher, J., J. P. Werner, J. E. Smerdon, L. Fernández-Donado, F. J. GonzálezRouco, D. Barriopedro, F. C. Ljungqvist, U. Büntgen, E. Zorita, S. Wagner, J. Esper, D. McCarroll, A. Toreti, D. Frank, J. H. Jungclaus, M. Barriendos, C. Bertolin, O. Bothe, R. Brázdil, D. Camuffo, P. Dobrovolný, M. Gagen, E. García-Bustamante, Q. Ge, J. J. Gómez-Navarro, J. Guiot, Z. Hao, G. C. Hegerl, K. Holmgren, V. V. Klimenko, J. Martín-Chivelet, C. Pfister, N. Roberts, A. Schindler, A. Schurer, O. Solomina, L. von Gunten, E. Wahl, H. Wanner, O. Wetter, E. Xoplaki, N. Yuan, D. Zanchettin, H. Zhang, and C. Zerefos. "European Summer Temperatures since Roman Times." Environmental Research Letters 11, no. 2 (2016). doi.org/10.1088/1748-9326/11/2/024001.

Majdán, János. "Magyarország közlekedése" [Transportation System in Hungary]. In Magyarország történeti földrajza, vol. 2 [The Historical Geography of Hungary, vol. 2], edited by Pál Beluszky, 72-110. Budapest-Pécs: Dialóg Campus Kiadó, 2008. 
Mendöl, Tibor. Általános településföldrajz [General Geography of Settlements]. Budapest: Akadémiai Kiadó, 1963.

Mendöl, Tibor. Táj és ember: Az emberföldrajz áttekintése [The Landscape and the Human: Review of Anthropogeography]. Budapest: Magyar Szemle Társaság, 1932.

Mezősi, Gábor. Magyarország természetföldrajza [The Physical Geography of Hungary]. Budapest: Akadémiai Kiadó, 2011.

Mikszáth, Kálmán. "Beszélő köntös" [The Talking Robe]. In Mikszáth Kálmán munkái 8: Kisebb regények. A fekete kakas. A beszélő köntös [Works of Kálmán Mikszáth, vol. 8. Shorter Novels: The Black Rooster. The Talking Robe], edited by Országos Jubileumi Bizottság, 67-191. Budapest: Révai Testvérek Irodalmi Intézet Részvénytársaság, 1910.

Molnár, Ambrus. "Határhasználat a Bihar megyei Sápon a XIX. században [Land Use of Sáp in Bihar County in the $19^{\text {th }}$ Century]." Agrártörténeti Szemle 10, no. 3-4 (1968): 514-51.

Molnár, Ambrus. "Nagyrábé népének gazdálkodása a török hódoltság után” [Agricultural Management Utilized by the Population of Nagyrábé after the Ottoman Occupation]. Agrártörténeti Szemle 14, no. 3-4 (1972): 398-422.

Móricz, Zsigmond. "A magyar gyümölcs nemzeti kincs" [Hungarian Fruit as a National Treasure]. In Riportok 2. (1920-1929) [Reports (1920-1929)], 241-45. Budapest: Szépirodalmi Könyvkiadó, 1958.

Nagy, Imre. Tücsök a máglyán [Cricket on the Bonfire], edited by József Pintér. Budapest: Szépirodalmi Könyvkiadó, 1971.

Németh, László. Kisebbségben, vol. 1 [In Minority]. Budapest: Magyar Élet, 1942.

Novák, László Ferenc. A Három Város néprajza [Ethnography of the "Three Towns"]. Debrecen: Debreceni Egyetem Néprajzi Tanszék, 2015.

Novák, László. A három város [The “Three Towns"]. Budapest: Gondolat Kiadó, 1986. Orosz, István. Tanulmányok az Alföld mezőgazdaságáról [Studies on Agriculture in the Great Hungarian Plain]. Debrecen: Debreceni Egyetem Történelmi Intézete, 2020.

Orosz, István. "Árforradalom, konjunktúrák és válságok" [Price Revolution, Booms, and Depressions]. In Európa az újkorban (16-18. század) [Europe in the Early Modern Period (in the $16^{\text {th }}-18^{\text {th }}$ Centuries)], edited by István Orosz, János Barta, and János Angi, 28-34. Debrecen: Multiplex Media - Debrecen University Press, 2006.

Öri, Péter. "A természetes szaporodás alakulása és helyi változatai a 18. századi Magyarországon" [The Evolvement and Local Variations of Natural Reproduction in $18^{\text {th }}$ Century Hungary]. In Történeti demográfiai évkönyv 2001 [Historical Demographic Yearbook 2001], edited by Tamás Faragó and Péter Öri, 193-222. Budapest: KSH Népességtudományi Kutatóintézet, 2001. 
Papp, Imre. "A népességviszonyok" [Population Relations]. In Európa az újkorban (16-18. század) [Europe in the Early Modern Period (during the $16^{\text {th }}-18^{\text {th }}$ Centuries)], edited by István Orosz, János Barta, and János Angi, 22-7. Debrecen: Multiplex Media and Debrecen University Press, 2006.

Papp, István. A magyar népi mozgalom története 1920-1990 [The History of the Hungarian "Popular Movement" between 1920-1990]. Budapest: Jaffa Kiadó, 2012. Papp, Klára. Biharország jobbágynépe. A magánbirtok és jobbágysága a XVIII. században [The Villeins of "Bihar Country". Private Land and its Villeins in the $18^{\text {th }}$ Century]. Debrecen: Csokonai Kiadó, 1998.

Pécsi, Márton. Negyedkor és löszkutatás [Quaternary and Loess Research]. Budapest: Akadémiai Kiadó, 1993.

Pénzes, János. "Fejlettségi különbségek és centrum-periféria viszonyok a történelmi Magyarországon (1910)" [Development Differences and Centre-Periphery Relations in the Historical Hungary (1910)]. In Területi egyenlötlenségek nyomában a történeti Magyarországon. Módszerekés megközelitések [Terri-torial Inequalities Investigation in the Historical Hungary: Methods and Approaches], edited by Gábor Demeter and János Szulovszky, 85-116. Budapest-Debrecen: Magyar Tudományos Akadémia Bölcsészettudományi Kutatóközpont and Debreceni Egyetem Társadalomföldrajzi és Területfejlesztési Tanszék, 2018.

Pinke, Zsolt. "Alkalmazkodás és felemelkedés - modernizáció és leszakadás: kis jégkorszaki kihívások és társadalmi válaszok a Tiszántúlon” [Adaptation and Rise - Modernization and Decline: Little Ice Age Challenges and Social Responses in the Transtisza Region]. PhD diss. University of Pécs, 2015. Accessed 26 October 2021. https://pea.lib.pte.hu/handle/pea/14972?show=full.

Puskás, Julianna. "Kivándorlás Magyarországról az Egyesült Államokba 1914 elött" [Emigration Waves from Hungary to the United States before 1914]. Történelmi Szemle 17, no. 1-2 (1974): 32-67.

Puskás, Julianna. Kivándorló magyarok az Egyesült Államokban 1880-1940 [Emigrant Hungarians in the United States in 1880-1940]. Budapest: Akadémiai Kiadó, 1982.

Rácz, István. "A parasztok elvándorlása a faluból” [The Emigration of Peasants from Villages]. In A parasztság Magyarországon a kapitalizmus korában 2., 18481914 [The Peasants' Status in Hungary during the Era of Capitalism, 1848-1914, vol. 2], edited by István Szabó, 433-86. Budapest: Akadémiai Kiadó, 1965.

Rácz, István. "A tanyarendszer kialakulása" [The Emergence of the Homestead System]. In Parasztok, hajdúk, cívisek: Társadalomtörténeti tanulmányok [Peasants, Hajdus and Civilians: Social Historical Studies], 317-80. Debrecen: Debreceni Egyetem, Kossuth Egyetemi Kiadó, 2000.

Rácz, István. Városlakó nemesek az Alföldön 1541-1848 között [Town-Dwelling Nobles in the Great Hungarian Plain in 1541-1848]. Budapest: Akadémiai Kiadó, 1988. 
Rácz, Lajos. “Mezőgazdasági terméskatasztrófák időjárási profilja a kis jégkorszak idején a tradicionális kori Magyarországon (1500-1850)" [Weather Profile of Agricultural Crop Disasters during the Little Ice Age in Hungary of Traditional Age (1500-1850)]. Légkör 64, no. 2 (2019): 4-7.

Rácz, Lajos. “Mi a kis jégkorszak?” [How can the Little Ice Age be Defined?]. Történeti Földrajzi Közlemények 4, no. 1 (2016): 15-46.

Rácz, Lajos. A kis jégkorszak éghajlati változásainak hatása az öszi búza terméseredményeire a Kárpát-medencében a reformkor idején [The Climate Change Effects of Little Ice Age Exerted on Autumn Wheat Yield Production in the Carpathian Basin in the Reform Era]. 2021. (Forthcoming.)

Rácz, Lajos. Magyarország éghajlattörténete az újkor idején [The Climate History of Hungary in the Modern Age]. Szeged: Juhász Gyula Felsőoktatási Kiadó, 2001. Romsics, Ignác. A trianoni békeszerződés [The Trianon Peace Treaty]. Budapest: Osiris Kiadó, 2007.

Solymosi, László. “A tanyarendszer középkori előzményeinek historiográfiája” [The Historiography of the Medieval Roots of the Homestead System]. In A magyar tanyarendszer múltja: Tanulmányok [The Past of the Homestead System: Studies], edited by Ferenc Pölöskei and György Szabad, 71-96. Budapest: Akadémiai Kiadó, 1980.

Somogyi, Imre. Kertmagyarország felé [In the Direction of "Garden Hungary"]. Budapest: Magyar Élet, 1942. (2nd ed. Budapest: Magyar Élet, 1943.)

Szabó, Ferenc. Két és fél évszázad az Alföld történetéböl. Válogatott tanulmányok [Two and a Half Centuries from the History of the Great Hungarian Plain. Selected Studies]. Szeged: Békés Megyei Levéltár and Csongrád Megyei Levéltár, 2008.

Szabó, Kálmán. Kecskeméti tanyák [Homesteads of Kecskemét]. Kecskemét: Kecskeméti Lapok, 1936.

Széchenyi, István. Eszmetöredékek, különösen a Tisza-völgy rendezését illetöleg [Fragments of Theory Fractures, Focusing on the Tisza Valley Restructuring]. Pest: Trattner és Károlyi, 1846.

Szilágyi, Zsolt. "Az alföldi piacközpont-állomány változása 1828-1925 között” [The Market Centers' Change between 1828 and 1925 on the Great Hungarian Plain]. Történeti Tanulmányok 23 (2015): 196-222.

Szilágyi, Zsolt. "A fejlettség területi különbségei az Alföldön a 20. század elején” [Territorial Differences of Development within the Great Hungarian Plain at the Beginning of the $20^{\text {th }}$ Century]. In Föld, parasztság, agrárium. Tanulmányok a XX. századi földkérdésröl a Kárpát-medencében [The Land, Peasants, Agriculture. Studies on Land Issues of the Carpathian Basin in the $20^{\text {th }}$ Century], edited by Zsuzsanna Varga and László Pallai, 37-112. Hajdúnánás: DE Történelmi Intézet, DE Történelmi és Néprajzi Doktori Iskola, Hajdúnánás Város Önkormányzata, ELTE Új- és Jelenkori Magyar Történelem Doktori 
Program, and MTA Agrártörténeti és Faluszociológiai Osztályközi Állandó Bizottság, 2015.

Szilágyi, Zsolt. "A térinformatika és a gravitációs modell szerepe a városhiányos területek megjelenítésében a két világháború közötti Alföld példáján” [Visualizing Areas Lacking Cities: A Possible Application of the Geographic Information System (GIS) and the Gravity Model in History, Based on the Example of the Great Hungarian Plain in the Interwar Period]. Új Nézőpont 4, no. 2 (2017): 31-69.

Szilágyi, Zsolt. Föld és hatalom: Mezővárosi elit Kecskeméten 1920-1939 [Land and Power: The Elite of Market Towns in Kecskemét in 1920-1939]. Budapest: L'Harmattan Kiadó, 2017.

Szilágyi, Zsolt. “A Kárpát-medence fejlettségi membránja (1910): a fogalomalkotás és a vizualizálás egy lehetséges módszertani megoldása, az eredmények kontextualizálási kísérlete" [The "Development Membrane" of the Carpathian Basin (1910): A Possible Methodological Solution for Conceptualization and Visualization an Endeavor to Contextualize the Results]. In Területi egyenlötlenségek nyomában a történeti Magyarországon. Módszerek és megközelitések [Territorial Inequalities Investigated in Historical Hungary: Methods and Approaches], edited by Gábor Demeter and János Szulovszky, 47-84. Budapest-Debrecen: Magyar Tudományos Akadémia Bölcsészettudományi Kutatóközpont and Debreceni Egyetem Társadalomföldrajzi és Területfejlesztési Tanszék, 2018.

Szilágyi, Zsolt. "Vándormozgalom a trianoni Alföld területén a 20. század első harmadában" [Internal Migration in the Post-Trianon Great Hungarian Plain in the First Third of the 20 ${ }^{\text {th }}$ Century]. Századok 152, no. 1 (2018): 85-126.

Szilágyi, Zsolt. “Az életminőség területi egyenlőtlenségeinek változása Magyarországon a 20. század első harmadában" [Changes in the Territorial Inequalities in Quality of Life in Hungary during the First Third of the $20^{\text {th }}$ Century]. In Területi egyenlötlenségek nyomában a történeti Magyarországon. Módszerek és megközelítések [Territorial Inequalities Investigated in Historical Hungary: Methods and Approaches], edition by Gábor Demeter and János Szulovszky, 255-334. Budapest-Debrecen: Magyar Tudományos Akadémia Bölcsészettudományi Kutatóközpontja, and Debreceni Egyetem Társadalomföldrajzi és Területfejlesztési Tanszéke, 2018.

Szilágyi, Zsolt. "Regional Differences in Development and Quality of Life in Hungary During the First Third of the Twentieth Century." Hungarian Historical Review 8, no. 1 (2019): 121-52.

Szilágyi, Zsolt. “Alkalmazkodó mezőváros: a kecskeméti tanyák kialakulásának éghajlattörténeti kontextusa" [The Adaptive Market Town: The Climate Historical Context of the Emergence of the Homestead System in Kecskemét]. Forrás 52, no. 7-8 (2020): 13-36. 
Szilágyi, Zsolt. "Alternatív Trianon, digitális forradalom” [Alternative Trianon and Digital Revolution]. In A Horthy-korszak vitatott kérdései [The Debated Issues of Horthy-Era], editey by HSA, 44-51. Budapest: Kossuth Kiadó, 2020.

Szilágyi, Zsolt. “Alföldi vonzáskörzetek és piacközpontok 1925-ben I: Módszertani megközelítések, vizsgálati keretek" [Catchment Areas and Market Centers in the Great Hungarian Plain in 1925. Part 1: Approaches of Methodology and Research Framework]. Agrártörténeti Szemle 55, no. 1-4 (2014): 107-56.

Szilágyi, Zsolt. “Az 1925. évi közigazgatási tájékoztató lapok forrásértéke és forráskritikája az alföldi községek példáján” [A Review of the Value of the 1925 Public Administration Information Circulars as Historical Sources]. In Vidéki élet és vidéki társadalom Magyarországon. A Hajnal István Kör - Társadalomtörténeti Egyesület 2014. évi, egri konferenciájának kötete [The Lifestyle and Society of the Countryside in Hungary: The Volume of the Conference Held in 2014 by The István Hajnal Circle - Hungarian Social History Association], edited by József Pap and Árpád Tóth, 94-112. Budapest: Hajnal István Kör Társadalomtörténeti Egyesület, 2016.

Szilágyi, Zsolt. “Sárrét posztmodern perspektívában: a táj történeti földrajza; az egységesülés és széttagolódás formái [Sárrét in a Postmodern Perspective: The Historical Geography of the Landscape; Forms of Unification and Division]. Tér és Társadalom 23, no. 2 (2009): 113-33.

Szilágyi, Zsolt. "Város-tanya-kapcsolat a Horthy-kori Kecskeméten” [Relationship between Towns and "Tanyas" in Kecskemét during the Horthy Era]. Tér és Társadalom 25, no. 2 (2011): 29-47.

Szilágyi, Zsolt. Homokváros. Kecskemét történeti földrajzi látószögek metszetében [The Sandtown. Historical Geographic Aspects Focusing on Kecskemét]. Kecskemét: Kecskemét Írott Örökségéért Alapítvány, 2012.

Thirring, Lajos. "A tanyák, puszták és egyéb külterületi lakotthelyek népessége 1930-ban" [The Population of Homesteads, Grasslands and Other Inhabited Peripheries in 1930]. Magyar Statisztikai Szemle 13, no. 12 (1932): 1044-62.

Tomka, Béla. Gazdasági növekedés, fogyasztás és életminőség: Magyarország nemzetközi összehasonlításban az első világháborútól napjainkig [Economic Growth, Consumption and Quality of Life: Hungary in an International Comparison from the First World War to the Present Day]. Budapest: Akadémiai Kiadó, 2011.

Toynbee, Arnold. “Tanulmány a történelemről (részlet)" [Study of History (fragment)]. In Történetelmélet, vol. 1. [Historical Theory], edited by János Gyurgyák and Tamás Kisantal, 688-710. Budapest: Osiris Kiadó, 2006.

Toynbee, Arnold. “Tanulmány a történelemröl” [Study of History]. In Válogatott tanulmányok [Selected Studies], translated by Márton Mesterházi, 13-218. Budapest: Gondolat Kiadó, 1971.

R. Várkonyi, Ágnes and László Kósa, eds. Európa híres kertje. Történeti ökológia 
tanulmányok Magyarországról [The Famous Garden of Europe. Studies in the Historical Ecology of Hungary]. Budapest: Orpheusz Könyvkiadó, 1993.

R. Várkonyi, Ágnes, ed. Táj és történelem [Landscape and History]. Budapest: Osiris Kiadó, 2000.

Veres, Péter. Az Alföld parasztsága [The Peasant Status of the Great Hungarian Plain]. Budapest: Oravetz István Könyvkiadóvállalat, 1936.

Weis, István. Mai magyar társadalom [The Hungarian Society in Recent Times]. Budapest: Magyar Szemle Társaság, 1930.

Wellmann, Imre. "Magyarország népességének fejlődése a 18. században" [The Hungarian Population's Development in the $18^{\text {th }}$ Century]. In Magyarország története tíz kötetben 4/1: Magyarország története 1686-1790 [The History of Hungary in Ten Volumes, Part 4/1: The History of Hungary between 16861790], edited by Győző Ember and Gusztáv Heckenast, 25-80. Budapest: Akadémiai Kiadó, 1989.

Zeidler, Miklós. A reviziós gondolat [The Theory of Revision]. Budapest: Osiris Kiadó, 2001. (2nd ed. Bratislava: Kalligram Kiadó, 2009.) 